Miron J. Musiat

Uniwersytet im. Adama Mickiewicza, Poznań

\title{
Transformacja, tranzycja, okres przejścia. Białoruś przelomu wieków
}

, I $\begin{aligned} & \text { ogłoby się wydawać, że Białoruś to państwo w pełni demokratyczne } \\ & \text { - naród wybrał prezydenta w demokratycznych wyborach, przeka- }\end{aligned}$ zanie władzy nastąpiło w sposób pokojowy. Ale wszystko było zupełnie inaczej - «partia władzy» zmieniła jedynie swoje oblicze i tylko tym można wytłumaczyć fakt, że nowy prezydent bez problemów zaadaptował się w środowisku"1. Powyższy cytat wymaga słów wyjaśnienia, gdyż diametralnie odmiennie niż większość autorów charakteryzuje proces, który miał miejsce na Białorusi w latach 1991-1994. Dodać należy na wstępie, iż jego autorzy nie są całkowicie w swoich osądach osamotnieni; wiele z nieznanych faktów z życia Aleksandra Grigorjewicza Łukaszenki ujawniają w nielegalnej na Białorusi pozycji Zwyczajny prezydent Paweł Szeremiet i Swietłana Kaliakin oraz - w wydanej w Moskwie - Łukaszenko polityczna biografia Aleksander Fieduta ${ }^{2}$. Większość politologów uważa, że w roku 1994 powstały na Białorusi system nosił znamiona typowe dla ówcześnie budowanych demokracji w pozostałych państwach byłego bloku sowieckiego - co, jak należy podkreślić, z politologicznego punktu widzenia nie budzi wątpliwości. Jest jednakże niewielka grupa badaczy i publicystów, którzy - być może mając rację - doszukuje się w tym procesie starannie sterowanego przejęcia władzy przez grupy w łonie nomenklatury, mające świadomość „,nadchodzącego krachu” systemu, w którym się wychowali; usiłujących zachować stan posiadania oraz wpływy [ekonomiczne]. Obraz, który wyłania się z publikacji Owsiannika i Striełkowej choć publicystyczny - ma charakter rzeczowego, popartego dowodami wywodu, precyzyjnego i dokładnego, bez zbędnego koloryzowania typowego dla niektórych wydań; z bogatą bazą źródłową. Poparcie Łukaszen-

1 S. Owsiannik, J. Striełkowa, Władza a społeczeństwo. Białoruś 1991-1998, Warszawa 1999, s. 103.

2 Fieducie nie można odmówić wiedzy o systemie; przez długi okres był on rzecznikiem prasowym prezydenta Aleksandra Łukaszenki. 
ki na jego drodze do prezydentury, i wcześniej - od właściwie pierwszej podjętej przez niego pracy wyglądają na celowe działanie, sprawnie realizowany plan. Nie istnieją jednak dostateczne dowody - poza poszlakami - by poparcie ex-sowieckich służb przyjąć za rzeczywistość.

***

Z. Blok przy deskrypcji etapu tranzycji posłużył się następującym określeniem: „tranzycja jest tym etapem, który jest obarczony dużym ryzykiem niepewności - występuje bowiem zagrożenie powrotu do starego reżimu. Ukształtowany po rozpadzie rządów autorytarnych system polityczny ma na ogół charakter hybrydoidalny - instytucje starego reżimu koegzystują z nowymi, stare elity polityczne dzielą się władzą z nowymi na zasadzie układu bądź w drodze konfliktu [...]. Tranzycja jest terminem, który można przypisać prawie wyłącznie do zmian politycznych, dotyczy bowiem tylko «zinstytucjonalizowania demokracji»". Z powyższej definicji wynikają dwa istotne fakty, mianowicie konieczność dokonania syntetycznego porównania okresu istnienia BSRR z tzw. łukaszyzmem, co ma dać odpowiedź na pytanie czy białoruski model przejścia ku demokracji [a pojmowany jako tranzycja] zakończył się w chwili dojścia do władzy Aleksandra Łukaszenki [lub później, zależy który moment przyjęty zostanie za odejście od budowy systemu demokratycznego i postawienie podwalin pod system autokratyczny]; oraz próbę zmierzenia, metodami obiektywnymi, siły społeczeństwa w parciu ku zmianie - co ma wyjaśnić kwestię czy proces został, czy też nie jest „umownie” zakończony. Literalne potraktowanie definicji prowadzić może do wypaczenia rezultatu badawczego: koniec procesu transformacji, jak i koniec procesu tranzycji jest trudny do jednoznacznego uchwycenia i zależy od zapatrywań badacza podejmującego problematykę. Traktując natomiast w sensie stricte wzmiankowany zapis o „ryzyku niepewności” postawić można w przypadku Rzeczpospolitej Polskiej hipotezę, iż sposób sprawowania władzy przez braci Kaczyńskich i obecną [2006/7 rok] ekipę rządzącą jest powrotem do tzw. pierwszosekretarstwa, co przekreśla zakończenie procesu konsolidacji jako odejście od demokracji. Podobny problem miał/ma miejsce w przypadku Ukrainy czy Federacji Rosyjskiej, gdzie - w pierwszym z wymienionych państw transformacja zakończyła się dopiero Pomarańczową Rewolucją, a w drugim - nie było transformacji, a tranzycja zakończyła się ponowną autokratyzacją w chwili dojścia do władzy Władimira Putina. To, jak elastycznie potraktowane zostanie pojęcie transformacji i tranzycji wpłynie właściwie jedynie na wyznaczenie daty końcowej 
owego procesu. Biorąc pod uwagę wydarzenia w Kirgistanie [Rewolucja Róż], Ukrainie [Pomarańczowa Rewolucja] oraz w Gruzji, trudno mówić o wydarzeniu wieńczącym przemiany. Wynika to $\mathrm{z}$ faktu, iż generalną tendencją początku XXI wieku na terenie Europy jest usuwanie [pomijając sposób dokonania usunięcia - na skutek wewnętrznego fermentu, zewnętrznej ingerencji bezpośredniej lub inspiracji] reżimów niedemokratycznych na rzecz tworzenia/przejścia ku reżimom demokratycznym. Konkludując, obecnie określana mianem stabilnie autorytarnej, sytuacja na Białorusi ewoluuje w bliżej nieokreślonym okresie ku systemowi demokratycznemu. Nie stanowi kwestii priorytetowej odpowiedź na pytanie, czy w przypadku Białorusi mamy do czynienia z transformacją, tranzycją czy konwersją wewnątrzsystemową, będącą szczególnym przypadkiem zachodzących zmian; wynika to $\mathrm{z}$ faktu, iż dla potrzeb niniejszej pracy znaczenie ma jedynie - $\mathrm{i}$ to umowne - punkt początkowy. Jak ujęła to Grażyna Strnad [niepublikowana dysertacja doktorska], „w analizie przejścia do demokracji można określić moment początkowy, strukturę procesu zmiany, a także jej wynik końcowy. Za początek tranzycji przyjmuje się moment sformułowania deklaracji o przeprowadzeniu rywalizacyjnych wyborów ${ }^{3}$, natomiast za wynik końcowy «zainstalowanie» systemu demokratycznego utożsamiane z przeprowadzeniem pierwszych rywalizacyjnych wyborów ${ }^{4}$, pierwszą alternacją władzy ${ }^{5}$, bądź najczęściej z konsolidacją demokratycznych reguł gry, w której element niepewności już nie występuje ${ }^{6}$ ". Początkiem okresu przejścia dla - ówcześnie jeszcze Białoruskiej Socjalistycznej Republiki Radzieckiej - jest data deklaracji niepodległości; nadal nie istnieje metoda badawcza wyznaczenia daty końcowej owego procesu.

Propozycje, możliwe do zaakceptowania w przypadku zachodnich, rozwiniętych i ugruntowanych demokracji nie znajdują zastosowania w badaniach, w których czynnikiem równania są państwa posowieckie.

3 J. J. Linz, Transitions to Democracy, „Washington Quarterly” 1990, vol. 13, no. 3, s. $150-152$.

${ }^{4}$ L. Morlino, Democratic Establishment: A Dimensional Analysis, w: Comparing New Democracies: Transition and Consolidation in Mediterranean Europe in the Southern Cone, red. E. A. Baloyra, Westview Press, Boulder CO-London 1987, s. 54.

5 D. Share, Transition to Democracy and Transition through Transaction, „Comparative Political Studies", January 1987, vol. 19, no. 4, s. 527.

${ }^{6}$ G. Pridham, Southern European Democracies on the Road to Consolidation, w: Securing Democracy: Political Parties and Democratic Consolidation in Southern Europe, red. G. Pridham, Routledge, London-New York 1990, s. 9. 
Doskonale owe niuanse charakteryzują m.in. Krygier i Czarnota, choć ich praca jest jedynie wstępnym [i pionierskim] zarysowaniem problematyki przeniesienia tradycyjnych, choć na poziomie świadomościowym nieustrukturalizowanych i nieoczywistych, działań do sfery legalnej. Podobną propozycję wysuwa Nina Antonowicz, wykładowca nauk politycznych Uniwersytetu Państwowego w Mińsku, zauważając - że by dokonać pełnej analizy systemu typu posowieckiego - należy wziąć pod uwagę co najmniej trzy jego elementy: 1) strukturę organów władzy (i ich wzajemne powiązania $^{7}$ ); 2) rolę biurokracji jako niezależnego aktora stosunków politycznych (lecz ów aspekt zawiera w sobie element subiektywnego stopniowania); 3) korupcję ${ }^{8}$. Fenomem korupcji uwypukla również Wołodymyr Połokhało, dyrektor ukraińskiego kwartalnika „Myśl polityczna”, w pozycji The political analysis of postcommunism, jednakże - odmiennie od Antonowicz - już we wstępie, wiążąc go z biurokracją. Samą korupcję określa jako „komponent mechanizmu, w którym machina biurokratyczna może wykorzystywać społeczeństwo", wskazując jednocześnie na element ,alienacji «of public servants»” [wyobcowanych i oderwanych od zarządzanego społeczeństwa] w badanym okresie.

Jak sformułował to Walenty Jakuszyk, ,jak pokazuje doświadczenie państw postkomunistycznych, korupcja tworzy specyficzną dystrybucję władzy lub, bardziej precyzyjnie, dystrybucję władzy pomiędzy różnego rodzaju polityków: pragmatyków lojalnych narodowemu liderowi, członków klanu lidera, osoby których wzajemne zaufanie i współpraca doprowadziły do pozbycia się innych ludzi, różnego rodzaju romantycy, których polityczna orientacja może różnić się od kulturalnych i politycznych poglądów większości, wreszcie - kręgi mafijne, reprezentujące narodowy kapitał kryminalny, zainteresowane jego uwiarygodnieniem oraz wtórna

7 Czyli klasyczne elementy ujęcia strukturalnego (instytucjonalnego), jak formułuje to m.in. S. Ehrlich, Z. Jarosz, S. Zawadzki, J. Kowalski, H. Lisiecka, J. Hausner i inni.

8 N. Antonowicz, The Structure and Transformation of Organs of Power in the Republic of Belarus, w: The Political System of Belerus and the 2001 Presidental Election, Warszawa 2001, s. 92-104. Patrz również: tzw. Corruption Perception Index, gdzie w zestawieniu 146 państw dokonanym przez Transparency International Białoruś zajęła 74 miejsce; Freedom House Report: The Worst of the Worst 2005 czy też A. Wielikij, Patrijnaja nomenklatura w komunisticzieskoj Biełarusi: 1917-1991. Sozdanie, razwitie, krah, „Informacionnyj biuletin. Statii i projekty wypusknikow amerykanskih programm obmiena", nr 8, październik-grudzień 2003. 
burżuazja"9. Wcześniej wymienił również, wśród grup zainteresowanych anomią struktur państwowych, osoby prywatne zaangażowane w nielegalne interesy, lecz również krajowe i zagraniczne firmy, organizacje polityczne i NGO, obce służby wywiadowcze. Nie umieszcza natomiast na liście szczególnie w świetle ostatniego wymienionego podmiotu - służb specjalnych danego państwa, co czyni m.in. Piotra Natczuk w artykule The belarusian nomenclature and line of cleavage in Lukashenka 's cadre policy ${ }^{10}$.

Odmienne zdanie - częściowo poparte danymi statystycznymi [choć te traktować należy jedynie jako przybliżone] wyraża A. Muhin; który Białoruś stawia w jednej linii z niektórymi państwami Zachodu porównując szare strefy w gospodarce ${ }^{11}$. Interesującą publicystyczną analizę, zbliżoną do wyżej wymienionych, lecz nieodległą od rzeczywistości, dał Herman Teutsch, zastępca redaktora naczelnego hiszpańskiego „El-Pais”, pisząc o „ogromnym więzieniu założonym przez politycznego mafiosa na północnym wschodzie Starego Kontynentu, na samej granicy Unii Europejskiej: W Europie ostał się już tylko Łukaszenko na czele połączonych sił mafii, aparatu administracyjnego, przemysłu, wojska i milicji”.

$* * *$

Ken Jowitt tuż po rozpadzie ZSRR napisał: „w 1989 roku blok sowiecki wyginął; partie komunistyczne dodały utratę władzy politycznej do wcześniejszej straty ideologicznego prawa bytu z okresu realnego socjalizmu; zaś Związek Radziecki - był już tylko tolerowany, ale przeznaczony do upadku. Rezultatem jest dziura w europejskiej koncepcji geografii, nie mniejsza niż w 1918 roku"12.

Interesującym pozostaje dlaczego region, w którym nigdy nie istniał - poza teoretycznymi i normatywnymi założeniami - komunizm - po 1991 roku nagle stał się postkomunistyczny. Jak twierdzą Czarnota i Kry-

9 W. Jakuszyk, Corruption in Postcommunist Societies, w: The Political Analysis of Postcommunism, red. W. Połokhajło, Kijów 1995, s. 164.

10 Natczuk dokonuje uporządkowania czynników, które wpływają na relacje wewnątrz białoruskiej nomenklatury w początkowych latach jej istnienia. Patrz: P. Natczuk, The belarusian nomenclature and line of cleavage in Lukashenka's cadre policy, w: The Political System of Belarus and the 2001 Presidental Election, Mińsk 2001, s. 105-121.

11 A. Muhin, Igra tieniej. Diengi KGB protiv dienieg KPSS, Moskwa 2005, s. 6-7. Patrz również: „Argumenty i Fakty” (kwiecień) 2001, nr 17.

12 K. Jowitt, The New World Disorder. The Leninist Extinction, Berkeley 1992, s. 284 . 
gier - „nalepka nie jest niewinna”, gdyż „reprezentuje pewien dokonany wybór i stawia kilka tez. Po pierwsze, w hybrydzie postkomunizm, nacisk powinien zostać położony na prefiks lub na sufiks. I to czyni różnicę. Jeśli region jest postrzegany jako przede wszystkim postkomunistyczny, to znaczy że uważamy komunistyczną przeszłość jako jakiś rodzaj snu lub koszmaru, który bezpowrotnie znika po przebudzeniu. Wielu świeżo upieczonych ekspertów i doradców z Zachodu usiłuje faworyzować tę interpretację, często bezrozumnie. Komunizm był przeszłością i prawdopodobnie zostawił śmieci, które należy usunąć; zaś postkomunizm jest teraźniejszością i przyszłością. Im bardziej w to wierzysz, tym mniej rozumiesz komunizm. Lecz jeśli bierzesz pod rozwagę region zwany postkomunistycznym, to pojawia się od razu oczywista sugestia że komunistyczna przeszłość, lub jej następstwa mają efekty w teraźniejszości. A to wydaje się głupie - próbować zrozumieć lub działać w dniu dzisiejszym, bez zrozumienia tego co go poprzedzało. Mądrość leży w determinacji nie tego, która $\mathrm{z}$ tych spolaryzowanych opcji powinna zostać wybrana, lecz jaka ich synteza rozjaśnia kompleksowość, sprzeczności i wybory postkomunistycznego świata. Po drugie: jest znacząca różnica lub niejasność [ang. bias - szum - M.M.] w tym terminie. Okres i stan rozwoju wypadków jest zdefiniowany tym, co go poprzedzało - przez to są one domniemanie post-raczej, niż tym czym są obecnie. To nie przypadek. Wiemy, lub przynajmniej nam się wydaje, że znamy naturę komunizmu. Nie znamy jednak natury tego co miało nadejść, lub nie jest jasnym czy wiemy. Po trzecie: nazywanie regionu postkomunistycznym jest wyborem znaczącego jednego elementu z przeszłości raczej niż innych. I choć wielu badaczy uważa to za naturalne, wcale takie nie jest. Przede wszystkim, państwa tego regionu chronologicznie zawsze będą postkomunistyczne, ale też są prócz tego post-różne inne, bez wyłączności tego pierwszego. I wiele $\mathrm{z}$ tych innych znaczeń ma również wpływ na współczesność - ,[r] ewolucyjne zmiany i ostatnie transformacje w postkomunistycznej Europie Środkowej... [a] pod powierzchnią szybkich zmian konstytucyjnych... znacznie wolniejsze procesy instytucjonalne i kulturalne zmiany, w których kontynuacja i stałość grają znacznie bardziej esencjonalną rolę"13.

Niejednoznaczność nie jest wyłącznie domeną badaczy prawa: wyrażenie tranzycja pochodzi od łacińskiego określenia transitio; lecz jego

\footnotetext{
13 J. Priban, P. Roberts, J. Young (red.), Systems of Justice in Transition, s. 1.
} 
rozumienie w j. polskim oparte jest głównie na bazie nomenklatury anglojęzycznej (fr. transition, ang. transition). Określa ono przejście [w wąskim znaczeniu tzw. proces demokratyzacyjny] od systemu niedemokratycznego (totalitarnego/autorytarnego) do systemu demokratycznego lub odwrotnie - od systemu demokratycznego do niedemokratycznego; zaś używając anglojęzycznej nomenklatury - do autokratyzmu, tj. systemu autorytarnego lub totalitarnego. Tak jak postkomunizm - o czym poniżej, czy demokracja - używana bez przymiotnika - jest terminem wieloznacznym, z domniemanym celem i charakterem. Zawężony termin używany jest dualnie ku określeniu - jak przyjmuje Z. Blok - wycinka rzeczywistości politycznej w danym państwie, bez analizy sytuacji gospodarczej czy społecznej lub polityki bezpieczeństwa ${ }^{14}$ lub fazy, której wynik nie jest znany $^{15}$. Zaznaczyć należy, iż większość autorów używa określenia tranzycja oraz transformacja [bez przymiotnika] zamiennie bez zasadniczej weryfikacji.

Białoruskie przemiany posiadają swe charakterystyczne wyróżniki, nietypowe dla państw przechodzących podobny proces; jednocześnie jednak noszą pewien generalny ryt, wspólny dla państw w okresie przejściowym. Jest to typowe, jako że ma związek z tą sferą działalności ludzkiej, która nie poddaje się sztampowym i eleganckim rozwiązaniom znanym $\mathrm{z}$ matematyki lub fizyki ${ }^{16}$. Oceniając przeobrażenia i stosując jako miarę krótki okres można postawić wręcz hipotezę, iż okres przeobrażeń na Białorusi zakończył się, zostając zastąpionym - używając neologizmu

14 Z. Blok, Teoria polityki. Studia, s. 104.

15 Z. Blok, Leksykon politologii, s. 611. Patrz również: M. Krygier, A. Czarnota, After Postcommunism: the Next Phase, „Annual Review of Law and Social Science” 2006, vol. 2, s. 306-307: „Transition is a situation, a condition, a predicament if you will, on a kind of indeterminate but whiggishly inclined trajectory from hateful past to liberal future. But in that space people make decisions, make mistakes, seek to serve their interests, etc., for many different reasons".

16 A. Wolff-Powęska ujmuje to w następujący sposób: „region środkowoeuropejski przyciaga uwagę jako określona całość zarówno poprzez podobieństwa, jak i zróżnicowanie. Na tym obszarze wspólnych doświadczeń „realnego socjalizmu” trwa proces poszukiwania nowej osobowości politycznej, wykazujący zdumiewająco wiele analogii. Jednocześnie jednak uwarunkowania międzynarodowe oraz uwolnienie pewnych procesów emancypacyjnych i narodowych zadecydowało tutaj o specyfice i szczególnej drodze transformacji”. Za: Oswojona rewolucja, s. 14-15. Temu służy również m.in. podział z pierwszego rozdziału wymienionej pozycji, gdzie autorka wyróżnia 3 perspektywy oceny wydarzeń: uniwersalną, regionalną i „szczególnej drogi”. 
B. Górowskiej - demokraturą ${ }^{17}$, sytuacją stabilnie autorytarną czy - jak chce Siergiej Siannikow - totalitaryzmem w początkowej fazie rozwoju ${ }^{18}$ [co jednak również znamionuje proces zmiany i ma również teoretyczną podbudowę wśród polskich badaczy]. Nie można oczywiście podważyć takiego toku rozumowania, jako że zależny jest on od potrzeb badawczych autora stawiającego hipotezę [Siannikow jest przedstawicielem antyłukaszenkowskiej opozycji, przewodniczącym Charter 97; przykładu próby modyfikacji rzeczywistości słowem pisanym dostarcza m.in. jego tekst The Accidental Dictatorship of Alexander Lukashenko opublikowany w opiniotwórczym SAIS Review w 2005 roku $^{19}$ ]. Jednakże większość badaczy, przyjmując do wiadomości i akceptując ,system demokratyczny" jako szczytowe osiagnięcie rozwoju typologii systemów politycznych umożliwiający nieskrępowaną partycypację i kultywowanie swobód obywatelskich etc., mając na względzie średni okres trwania dyktatury ${ }^{20}$, odrzuci stabilność a priori. Celowo nie podejmuję rozważań nad celowością i zasadnością dokonywania oceny pewnego wycinka obcej kultury [niezachodniej/prawosławnej] na bazie doświadczeń wypracowanych podczas tworzenia i umacniania „zdobyczy zachodniej cywilizacji”, gdyż po pierwsze: nie jest to cel niniejszej pracy, po drugie: materiał ma charakter

17 Za: M. Czerwiński, Białoruś, w: Systemy polityczne państw Europy Środkowej $i$ Wschodniej, red. E. Pioskowik, M. Barański, Katowice 2004.

18 A. Siannikow; Biełaruski tatalitaryzm - realność, www.charter97.org/bel/ news/2003/07/25/sannikov. Jak twierdzi Siannikow, ,ppoza masową monopartią występują [w systemie] właściwie wszystkie elementy państwa totalitarnego”.

19 Siannikow jest byłym ministrem spraw zagranicznych Białorusi; zrezygnował z funkcji w 1996 roku na znak protestu przeciw sfałszowanemu referendum. We wzmiankowanym tekście usiłuje rozprawić się z pięcioma mitami czy też błędnym odbiorem, który jego zdaniem istnieje w świadomości zachodnich badaczy Białorusi. Zaprzecza m.in. prawie nieistniejącej tożsamości narodowej, niskiemu znaczeniu i słabości opozycji białoruskiej, wysokiemu poparciu obecnego białoruskiego lidera na wsi czy zanikowi języka białoruskiego w powszechnej komunikacji.

20 ,Zarówno szanse oddziaływania, jak i możliwość konsolidacji oraz stabilizacji systemu w przypadku demokracji okazały się znacznie wyższe aniżeli w przypadku dyktatur. Podczas gdy próg przetrwania piętnastu lat, stwarzający umowną granicę odporności na zmiany, stał się już dla demokracji regułą, dla dyktatury jest on niemal nieprzekraczalny. Zjawisko to tłumaczy m.in. fakt, że dyktatura opiera się na autorytaryzmie jednostki. Jej załamanie, czy klęska są zazwyczaj jednoznaczne z upadkiem systemu". A. Wolff-Powęska, Oswojona rewolucja, s. 23. Kwestię trwałości podejmuje również Barbara Geddes w: What Do We Know about Democratization after Twenty Years?, „Annual Review of Political Science” 2, s. 115-144. 
zbyt obszerny nawet dla krótkiej dygresji, po trzecie: istnieją pozycje, które tę tematykę poruszają ${ }^{21}$.

J. Igrickij z Rosyjskiej Akademii Nauk określił, używając słów węgierskiego badacza Arpada Sakolczai'ego, ów fenomen następująco: „wraz z całą Europą Wschodnią [Rosja] wstapiła na permanentny stan przejścia”: „kruszenie porządku to trudne wyzwanie i może doprowadzić do poważnego kryzysu. Odpowiedź może przyjść tylko po długim okresie prób i błędów, albo wcale nie przyjść, jak pokazuje zanik wielu kultur i cywilizacji. Jeśli odpowiedź na kryzys nie przychodzi od razu, czasowy stan przejścia może się przedłużyć i społeczeństwo lub cała cywilizacja może utknąć w tym przedłużającym się przejściu, gdzie [stany] czasowe, przechodnie, nietypowe, efemeryczne i nadzwyczajne stanowią standard, normę, zwyczajność, przyjmowane są jako niezbędne. Dokładnie to stało się w Centralno-Wschodniej Europie"22. Sam określił natomiast czas po 1991 roku dla Rosji w następujący sposób: ,rosyjskich uczonych wyręcza rosyjska historia i znajomy dla niej ojczysty termin: smuta”.

Jeszcze mniej dogmatyczny okazał się P. Hassner, pisząc że „każdy charakteryzowany okres jest przechodnim, ale niektóre są bardziej prze-

21 Patrz m.in. J. Sobczak, Zmierzch cywilizacji, Poznań 2002; J. Diec Cywilizacje bez okien. Teoria Mikołaja Danilewskiego i późniejsze koncepcje monadycznych formacji socjokulturowych, Kraków 2002; pozycje M. Zdziechowskiego czy A. Jabłoński, który konkluduje: „główna oś konfliktu politycznego obecnej ery przebiega zdaniem Huntingtona między cywilizacją Zachodu a światem nie-zachodnim. Autor odrzuca tezę o uniwersalizacji wartości zachodnich. Podstawowe wartości zachodniej kultury politycznej są z wielkim trudem adaptowane w innych cywilizacjach. Zachodnie idee indywidualizmu, liberalizmu, konstytucjonalizmu, praw człowieka, równości, wolności, rzadów prawa, demokracji, wolnego rynku, rozdziału kościoła od państwaznajduja słaby rezonans w kulturach Islamu, Konfucjanizmu, Hinduizmu, Japanizmu, Buddyzmu i Ortodoksji”, za: A. W. Jabłoński, Kultura polityczna: tradycje i teorie, w: Teoretyczne i metodologiczne problemy badań nad kultura polityczna, red. Z. Blok, Poznań 2005, s. 20. Jest to oczywiście w pełni tożsame z rozumowaniem poczynionym przez Huntingtona, który pisał: „A wave of democratization is a group of transitions from nondemocratic to democratic regimes that occur within a specifed period of time and that significantly outnumber transitions in the opposite direction during that period of time. A wave also usually involves liberalization or partial democratization in political systems that do not become fully democratic". (Third Wave, s. 15). Poszczególne fale datują się na: First wave, long 1828-1926; First reverse wave 1922-1942; Second, short 1943-1962; Second reverse wave 1958-1975; Third wave 1974-present.

22 A. Sakolczai, In a Permanent State of Transition: Theorising the East European Condition, European University Institute working papers, s. 4. 
chodnie od innych"23. Z kolei L. Ray podważa część istniejących teorii konstatując: ,antykomunistyczne rewolucje oznaczają nie powrót do przeszłości, nie są konwergencją z współczesnością (obrazu zachodniego), lecz wynikaniem nowych struktur w bezprecedensowej jak dotąd sytuacji. Zachodnie koncepcje rozumienia sytuacji nie pasują do tych społecznych zmian" ${ }^{24}$; co podobne jest do percepcji J. Staniszkis, która uważa postkomunizm za fałszywy obraz [i jednocześnie umacnia stanowisko Owsiannika i Striełkowej]; gdyż wciąż u władzy pozostają te same jednostki: „,instytucje demokratyczne i wolnorynkowe w krajach postkomunistycznych są jedynie dekoracją utrzymujących się nadal rządów dawnej elity władzy" "25. Podobnie wyraża się Wolff-Powęska we wstępie do Oswojonej rewolucji: „praca nie uwzględnia regionu postsowieckiego”, thumacząc to od razu w następujący sposób: „zadecydował o tym zarówno czynnik ilościowy - wielość procesów transformacji w byłych republikach byłego Związku Radzieckiego oraz jakościowy - odmienność napiętnowanego wielowiekową tradycją carską oraz ponad siedemdziesięcioletnim totalitaryzmem komunistycznym obszaru zmian. Fakt, że społeczeństwa postsowieckie muszą uwolnić się od systemu totalitarnego rodzimego pochodzenia, narzuconego przez własne, a nieobce władze, ma określony wpływ na tempo i charakter przemian"26.

Jedno z istotnych założeń Huntingtona, wyrażone przez T. Carothersa, przyjmuje następującą formułę: „demokratyzacja rozwija się etapami [...]. Etap nie musi mieć charakteru ciągłego procesu, może zostać wstrzymany, odwrócony, przyśpieszony. Może również dojść do wstrzymania, przeciągnięcia lub odwrócenia którejś z faz podrzędnych"27.

\section{Szara strefa [gray zone]}

Analizując różnorakie propozycje teoretyczne i podejścia metodologiczne uważam, że przedstawić należy kilka istotnych założeń, które we

23 P. Hassner, The Priority of Constructing Western Europe, w: G. F. Treverton, Europe and America beyond 2000, s. 21.

24 L. J. Ray, Rethinking Critical Theory: Emancipation in an Age of Global Social Movements, s. 247.

25 J. Staniszkis, W poszukiwaniu paradygmatu transformacji, ISP PAN, s. 5-34.

26 A. Wolff-Powęska, Oswojona rewolucja, Instytut Zachodni 1998, s. 14.

27 T. Carothers, The End of Transition Paradigm, ,Journal of Democracy” 2002, 13:1, John Hopkins University Press, National Endowement for Democracy. 
właściwy sobie sposób charakteryzują mnogość koncepcji i brak jednoznacznych wskaźników, które należy czy można stosować. Klasykę stanowi - mimo swoich wad - Samuel Huntington, twórca Trzeciej Fali, który stwierdził m.in. iż „1) żaden pojedynczy czynnik nie jest wystarczający dla wyjaśnienia rozwoju demokracji we wszystkich krajach lub w jednym kraju; 2) żaden pojedynczy czynnik nie jest niezbędny dla rozwoju demokracji we wszystkich krajach; 3) demokratyzacja w poszczególnych krajach jest rezultatem szeregu przyczyn; 4) zestaw przyczyn prowadzących do demokracji jest różny w różnych krajach; 5) zestaw przyczyn leżących ogólnie rzecz biorąc u źródeł jednej fali demokratyzacji różni się od tych, które powodowały inne fale; 6) przyczyny leżące $\mathrm{u}$ podstaw pierwszego etapu zmian systemowych w fali demokratyzacji prawdopodobnie będą różne od przyczyn powodujących dalsze zmiany systemowe w danej fali" 28 .

Karol B. Janowski, w połowie lat dziewięćdziesiątych pisał: „z końcem lat osiemdziesiątych w krajach Europy Środkowej i Wschodniej doszło do zmian otwierających proces przeobrażeń, mający znamiona transformacji ustrojowo-politycznej i społeczno-ekonomicznej. Jednakowoż owe zmiany nie zostały poprzedzone prognozą, która zapowiadałaby finał dotychczasowego porządku. Zapewne stanowi to przyczynek do słabości teorii polityki, a zwłaszcza tej jej części, która dotyczy zmian politycznych. Wieloaspektowe ujęcie dziejącego się procesu wprawdzie nie gwarantuje pełnego obrazu, jednakże pozwala na uzyskiwanie co najmniej wstępnych odpowiedzi na pytania dotyczące genezy, uwarunkowań oraz przebiegu i skutków tego, co określane jest jako transformacja, tranzycja, przeobrażenia itp., ${ }^{, 29}$

Znaczenie dla niniejszego dyskursu mają również słowa Andrzeja W. Jabłońskiego, który, przywołując Z. Bloka, skonstatował: „transformacja systemowa to proces przechodzenia od społeczeństw totalitarnych lub autorytarnych do demokratycznych lub quasi demokratycznych, lub odwrotnie - od demokracji do autorytaryzmu (Blok, 1999)"30. Tenże autor, w pozycji Transformacja jako konwersja funkcji wewnatrzsystemowych

28 S. P. Huntington, Trzecia fala..., s. 48.

29 K. B. Janowski, Przeobrażenia polityczne $w$ Polsce a transformacja na Wschodzie, w: Polska wobec transformacji na Wschodzie, Materiały międzynarodowej konferencji naukowej, Poznań, 6-7 czerwca 1995 r., s. 39.

30 Z. Blok, Teoretyczne i metodologiczne problemy badań nad kultura polityczna, Poznań 2005. 
na przykładzie Polski definiuje transformację, używając pojęcia konwersji; proces po 1989 roku zyskał miano rekonwersji, konwersja (proces pierwotny) umiejscowiony został zaraz po drugiej wojnie światowej jako totalizacja okresu stalinizmu. Dla Białorusi ujęcie takie - z racji uwarunkowań historycznych - nie może zostać zastosowane; konwersja z racji faktu istnienia państwa białoruskiego jako podmiotu prawa międzynarodowego jedynie przez kilkanaście lat nie miała miejsca.

Siła każdej teorii - co nie wymaga w żadnym wypadku jakiegokolwiek komentarza - tkwi w możliwości jej praktycznego udowodnienia, zastosowania w rzeczywistości, wyniesienia poza grunt teoretyczny. $Z$ prawie 100 państw $^{31}$, określanych $\mathrm{w}$ ostatnich latach jako „w okresie tranzycji/przejścia", zaledwie 20 jest obecnie funkcjonującymi lepiej [liberalnymi] lub gorzej [elektoralnymi] demokracjami. Wśród nich - o czym wspomina Larry Diamond w Is the Third Wave Over ${ }^{32}$ jest i Polska, i państwa Pribaltiki, i Południowa Korea. Jak ujęli to Aurel Croissant i Wolfgang Merkel, ,jest to dość pesymistyczna wizja [trzeciej fali]. Jak wskazują empiryczne dowody, że w pewnym momencie trzecia fala demokratyzacji może stać się w mniejszym stopniu tryumfem politycznego liberalizmu i liberalnej demokracji, a bardziej tryumfem hybrydowych lub wieloznacznych reżimów [ambiguous regimes], delegowanych, uszkodzonych, pót-, nieliberalnych demokracji, wspótzawodniczqcego/rywalizacyjnego [competitive] autorytaryzmu lub autorytaryzmu wyborczego. Systemy te tworzą potiomkinowskie demokracje, gdzie fasada demokracji przykrywa autorytarne, etnokratyczne, plebiscytowo-populistyczne metody sprawowania władzy; często z cechami sułtańskimi [sultanistic] stąd określenie fałszywe demokracje. Częstokroć są to demokracje elektoralne [wyborcze], z mniej lub bardziej wolnymi wyborami; w których jednak - jak to określa O’Donnell - wiele segmentów społeczeństwa posiada obywatelstwo o niskiej intensywności [...]. Przez wiele lat w literaturze panowała tranzycjologia i konsolidacjologia, łączące wiarę w to, że nowe demokracje mogą wybrać jedynie jedną z dwóch dróg rozwoju: powrót do systemu niedemokratycznego lub konsolidację liberalnej demokracji. Rzeczywistość polityczna opowiedziała inną historię: problem instytucjonalizacji liberalnej demokracji nie jest posadowiony na adopcji nowej konstytucji i implementacji wolnych i uczciwych wyborów - jakkolwiek

31 Około 20 w Ameryce Łacińskiej, 25 w Europie Wschodniej i byłym Związku Radzieckim, 30 w regionie subsaharyjskim, 10 w Azji i 5 na Bliskim Wschodzie.

32 „Journal of Democracy” (lipiec 1996), s. 20-37. 
mierzonych i definiowanych. Coraz więcej reżimów na świecie dokonuje syntezy - w różnym stopniu - demokratycznych form i instytucji z autorytarnymi tendencjami, bez podążania stricte ścieżką demokracji lub autorytaryzmu [...]". Nie mniej istotne jest ostatnie zdanie owej wypowiedzi, w którym twórca podstaw merytorycznych wykorzystanych przez S. Huntingtona - Guillermo O'Donnell, skrytykował podejście, w którym trwające po 20 lat reżimy [wciąż] są traktowane jako „w fazie przedłużającego się nieskonsolidowania"33.

Rozważając niniejszą kwestię, mieć na względzie należy, iż brakuje jednorodnego modelu, który w sposób teoretyczny charakteryzowałby zmiany dokonujące się w chwili obecnej w przestrzeni posowieckiej i pasowałby kompleksowo do owych zmian. Dotychczasowe modele, teorie, paradygmaty miały mniejsze lub większe pokrycie w rzeczywistych wydarzeniach [tak dla teoretyków, jak i praktyków pomocy międzynarodowej], lecz głównie dla państw spoza bezpośredniego byłego bloku wschodniego. Nie jest to bynajmniej krytyka, lecz raczej wskazanie odmienności dróg rozwoju podmiotów prawnomiędzynarodowych, wywodzących się ze związu bratnich republik socjalistycznych; wciąż słabo rozumianych. Przypomnieć wystarczy, że rozpad Związku Socjalistycznych Republik Radzieckich - z dnia na dzień właściwie - stanowił zaskoczenie dla większości tzw. sowietologów. Pomarańczowa rewolucja, jak stwierdził Czarnota - dopiero w 2005 roku zamknęła etap określany mianem pokomunizmu na Ukrainie, zaś Gruzja - przyjmując spiskową teorię dziejów [o rewolucji wiedzieli jej mocodawcy z Waszyngtonu] wybrała szlak przetarty przez Ukrainę również bez ostrzeżenia właściwie, wymykając się propozycjom teoretycznym. Republiki posowieckie są szarą strefą, strefą która nie poddaje się jednoznacznym i łatwym rozwiązaniom $^{34}$. Tranzycja - jako przejście ku demokracji? Czy tranzycja - jako stan? Czy też raczej - tranzycja jako odejście od demokracji? Nie są to jedyne pytania, które pojawiły się przy - błahej wydawać by się mogło kwestii - wskazania jedynie okresu, który ma być badany - tj. po 1991 roku; stworzenia odpowiednich ram czasowych. Czy transformacja nie zacho-

33 G. O'Donnell, Illusions about Consolidation, w: red. L. Diamond, Consolidating the Third Wave Democracies. Themes and Perspectives, Baltimore-London 1997, s. 44.

34 Larry Diamond używa również terminu strefa zmierzchu odnosząc się do grupy państw „trwających bez legitymizacji lub instytucjonalizacji”. L. Diamond Developing Democracy: Toward Consolidation, Baltimore 1999, s. 22. 
dzi, gdy system z demokratycznego staje się autorytarny, a przesłanki świadczą, że to dopiero początek drogi ku lekkiej formie totalitaryzmu? Czy na Białorusi trwa proces transformacji, który zakończy się demokracją? W jakim terminie? Jakiego rzędu będzie to skala? Lat czterech czy czterdziestu? I czy - co jest kwestią rudymentarną - przesłanki są właściwe? Wskazują na możliwe zmiany czy są rodzajem pobożnych życzeń popleczników [bez negatywnych konotacji] antyłukaszenkowskiej opozycji?

$* * *$

Dla Białorusi możliwa jest co najmniej dychotomiczna deskrypcja zachodzących tam procesów[u] z punktu widzenia badania transformacji/tranzycji - nie przesądzając o konkretnych rozwiązaniach. Pierwsza opiera się na twierdzeniu, że po 1995[6] roku zachodzący tam proces jest wciąż transformacją, jednakże $\mathrm{z}$ odwróconym kierunkiem [wektorem] zmian - zgodnie z propozycją metodologiczną m.in. A. Jabłońskiego nawiązującego do Z. Bloka; T. Reichelta, I. Kobrinskiej ${ }^{35}$, A. Patupy ${ }^{36}$ czy B. Albina i W. Baluka. Na mocy drugiej, teoretycznej propozycji - a jej przedstawicielami są m.in. Aurel Croissant i Wolfgang Merkel - Białoruś przeszła do tzw. szarej strefy - wymykającej się klasycznemu rozumieniu przejścia - zaś przyjęcie ustawy zasadniczej w 1994 roku i wolne wybory są jedynie fasadą dla kontynuacji niedemokratycznego reżimu; demokracji zarządzanej, sułtanizmu, nieliberalnej demokracji ${ }^{37}$. Ten sposób myślenia obarczony jest wadą i pewną dozą tzw. spiskowej teorii dziejów, zakłada bowiem, po części nieświadomie, jako tło m.in. planową intro-

35 I. Kobrinskaja, Długi koniec zimnej wojny, Warszawa 1998, s. 16: „chociaż transformacja Europy Środkowo-Wschodniej i przestrzeni postsowieckiej daleka jest od zakończenia, niemniej jednak w latach 1995-1996 ostatecznie ukształtował się zestaw czynników oraz kontekst, które określają rozwój stosunków między Rosją i państwami Europy Środkowo-Wschodniej”.

36 „backward phase transition to totalitarism”, za: A. Patupa, Mass Media and Controlling Mechanisms, w: Media in Post-Communist Societies: Objective Information vs. Ideological Bias, red. A. Ancipienka, s. 152.

37 Co zbieżne jest z oryginalną koncepcją G. O’Donnella i P. Schmittera [bez modyfikacji wniesionych przez S. Huntingtona], którzy kładli nacisk na fakt, że produkt przejścia jest niepewny i dopuszcza wariacje: może dać demokrację, lecz może również przejść w zliberalizowany reżim autorytarny (tzw. dictablanda) lub w restrykcyjną, nieliberalną demokrację (demokratura/democradura). G. O’Donnella, P. Schmittera, Transitions from Authoritarian Rule: Tentative Conclusions About Uncertain Democracies, Johns Hopkins University Press, Baltimore 1986, s. 9. 
dukcję Aleksandra Łukaszenki na stanowisko prezydenta republiki oraz to, że obecny system ma charakter raczej bardziej demokratyczny niż autorytarny - co jest dość - dyplomatycznie określając - zastanawiające. Na korzyść tej teorii przemawiają niektóre z tez Thomasa Carothersa: „część państw szarej strefy posiada demokratyczne życie polityczne, włączając co najmniej ograniczone polityczne pole dla opozycyjnych partii i niezależnego społeczeństwa obywatelskiego, jak również regularne wybory i demokratyczne konstytucje. Zastrzeżenia poważnych braków demokracji istnieją $\mathrm{z}$ powodu słabej reprezentacji interesów obywateli, niskiego poziomu partycypacji politycznej poza głosowaniem, częste łamanie prawa przez urzędników państwowych, wybory sankcjonujące niepewną legitymizację, bardzo niskie zaufanie dla organów państwa oraz permanentnie niska wydajność państwa jako organizacji”. Stąd, jak kontynuuje Carothers - powstało wiele określeń na ów stan między otwartą dyktaturą a ustabilizowaną demokracją: semi-demokracja, demokracja formalna, demokracja elektoralna [wyborcza], fasadowa demokracja, pseudo-demokracja, słaba demokracja, częściowa demokracja, nieliberalna demokracja czy demokracja wirtualna ${ }^{38}$; zaś opisywanie przez analityków państw w szarej strefie jako demokracji stawia paradygmat tranzycji pod znakiem zapytania [„,calling that paradigm into question”] ${ }^{39}$, bowiem większość uznanych terminów dotyczących demokracji używanych jest w przypadku państw, które utknęły gdzieś pośrodku sekwencji demokratyzacyjnej, zwykle na poczatku fazy konsolidacji.

Ciekawą tezę - i jest to dotąd jedyny autor, który w ten sposób przedstawił proces przejścia - postawił Kirył Koktysz, docent w Katedrze Teorii Politycznej MGIMO Ministerstwa Spraw Zagranicznych FR ${ }^{40}$. „The Belarusian presidential campaign marked the end of the country's imitative transition and the beginning of its real transition". Co jednak należy podkreślić, również Koktysz zamiennie używa transition, transformation i perechod [pieriod pieriechoda] ${ }^{41}$.

38 D. Collier, S. Levitsky, Democracy with Adjectives: Conceptual Innovation in Comparative Research, „World Politics” (kwiecień) 1997, nr 49, s. 430-451.

39 G. O’Donnell, Delegative Democracy, „Journal of Democracy”, January 1994, s. $55-69$.

40 Moskiewski Państwowy Instytut Spraw Międzynarodowych.

41 W mojej opinii rosyjskojęzyczny termin przejście lub okres przejścia jest jednym z najbardziej adekwatnych. 
Zauważyć należy, iż powyższe propozycje za swą podstawę przyjmują zmodyfikowaną teorię Samuela Huntingtona; po części zdezaktualizowaną, niedostosowaną do rzeczywistości początku XXI wieku i krytykowaną przez wielu badaczy. Podstawę owej krytyki wyznaczył wzmiankowany już Carothers, negujący dotychczasowy klasyczny, przyjęty i rozwijany paradygmat - jak to określa - tranzytologów, amerykańskich badaczy tworzących na potrzeby amerykańskiego eksportu demokracji modele teoretyczne, niewiele - co stanowi oś krytyki Carothersa ${ }^{42}$ - mające obecnie wspólnego z praktyką. By przybliżyć wyżej przywołane poglądy, należy cofnąć się do 2002 roku, gdy Carothers publikuje w prestiżowym „Journal of Democracy” wydawanym przez John Hopkins University wspólnie z National Endowement for Democracy tekst The End of Transition Paradigm, gdzie rozpoczyna od przedstawienia syntetycznych siedmiu subprocesów zmian na świecie w ciągu ostatniego ćwierćwiecza dwudziestego wieku [tj.: 1) upadek prawicowych reżimów autorytarnych w południowej Europie w połowie lat siedemdziesiątych; 2) wymiana dyktatur wojskowych przez cywilne władze w Ameryce Południowej przypadająca na okres od późnych lat siedemdziesiątych do późnych lat osiemdziesiątych ${ }^{43}$; 3) odejście od rządów autorytarnych w części Wschodniej i Południowej Azji począwszy od połowy lat osiemdziesiątych; 4) upadek reżimów komunistycznych w Europie Wschodniej pod koniec lat osiemdziesiątych ${ }^{44}$; 5) rozpad Związku Socjalistycznych Republik Radzieckich i ustanowienie piętnastu nowych jednostek - podmiotów prawa międzynarodowego w 1991 roku; 6) usunięcie jednopartyjnych systemów w wielu częściach Afryki sub-saharyjskiej w pierwszej połowie lat dziewięćdziesiątych oraz 7) słaby, lecz zauważalny trend liberalizujący w niektórych państwach Środkowego Wschodu w latach dziewięćdziesiątych]. Co najistotniejsze w dyskursie - przemiany te, symultaniczne, wpływające na siebie wzajemnie, w rezultacie potraktowane zostały jako jeden proces, czego wyrazem była generalna akceptacja propozycji Samu-

42 Thomas Carothers jest autorem m.in. Aiding Democracy Abroad: The Learning Curve (1999) i współautorem (z Mariną Ottaway) Funding Virtue: Civil Society Aid and Democracy Promotion (2000). Przy tworzeniu pierwszej wersji Carothers brat pod uwagę krytyczne uwagi m.in. D. Brumberg, Ch. King, M. McFaul, M. Ottaway, Chrisa Sabatini oraz M. Shifte.

43 Choć tę tendencję latwo obalić, przywołując dane przedstawione przez Wolff-Powęską. Patrz: Oswojona rewolucja, s. 22 i n.

${ }^{44}$ Co dziwi, ze względu na nieujęcie Europy Środkowej w wyliczeniu. 
ela Huntingtona - tzw. Trzeciej Fali [Demokratyzacji] w środowiskach politycznych prawicowych elit Stanów Zjednoczonych. Najbardziej jednak zainteresowany ową propozycją teoretyczną był - co skrupulatnie podkreśla Carothers - amerykański rząd [administracja R. Regana, określająca w owym okresie Związek Radziecki mianem Imperium Zła i rozbudowująca SDI] i szersza wspólnota rządowych, quasi-rządowych i pozarządowych organizacji tworzących amerykańską politykę zagraniczną [poza dyskursem: oczywiście - co jest moim jedynie dodatkiem zawężenie owego przyjęcia do rozszerzenia rynków zbytu byłoby zbytnim uproszczeniem, lecz - być może - całkiem uzasadnionym?]. Od połowy lat osiemdziesiątych tak R. Regan, jak i George Shultz [sekretarz stanu] jak mantrę powtarzali wyrażenie ,światowa rewolucja demokratyczna"; co wymagało utworzenia - i co zostało wsparte, pod naciskiem paradygmatem obrazującym ów proces. Carothers wyraził to w następujący sposób: „this new democracy-promotion community had a pressing need for an analytic framework to conceptualize and respond to the ongoing political events [...]. It was derived principally from their own interpretation of the patterns of democratic change taking place, but also to a lesser extent from the early works of the emergent academic field of transitology, above all the seminal work of Guillermo O'Donnell and Philippe Schmitter ${ }^{45}$. Najważniejszy element owego procesu znajduje ujście jednak w chwili obecnej - bowiem paradygmat tranzycji, opisany powyżej, mimo swego niedostosowania do [niedemokratycznej] rzeczywistości, stosowany jest permanentnie do dziś; mimo degradacji poczynionej na oryginalnej koncepcji przez jej krytyków. Carothers, przedstawiając podstawowe pięć założeń, które legło u podstaw koncepcji przejścia Huntingtona, wymienia:

1) podstawowe i pierwsze założenie, będące jednocześnie podstawą pozostałych czterech jest takie, iż zaistniało odejście od reżimu dyktatorskiego; państwo określane jest wtedy jako „w okresie przejściowym ku demokracji" [can be considered a country in transition toward democracy]; pojęcie to jest na tyle szerokie, że - jak zauważa sam Carothers - znalazła się w tej grupie nawet Demokratyczna Republika Konga [Kinszasa], targana wojną domową, przewrotami i masowym

$45 \mathrm{Tj}$. na podstawie pracy Transitions from Authoritarian Rule: Tentative Conclusions About Uncertain Democracies, Johns Hopkins University Press, Baltimore 1986. 
ludobójstwem ${ }^{46}$; można tu też umieścić - dzięki tak szerokim kryterium - Białoruś;

2) drugie założenie: demokratyzacja rozwija się etapami, określonymi jako „otwarcie” [ferment i polityczna liberalizacja, załamanie się rządów starego typu], ,przełom” [szybki rozwój nowego, demokratycznego reżimu, dojście do władzy poprzez wolne wybory, często promulgacja nowej ustawy zasadniczej], „konsolidacja” [regularyzacja zasad wyborczych, utrwalenie instytucji demokratycznych utworzonych w fazie przełomu, wzmocnienie instytucji społeczeństwa obywatelskiego, ogólne przyzwyczajenie do nowych reguł demokratycznej gry]; etap ów nie musi mieć ciągłego procesu, może zostać wstrzymany, odwrócony, przyśpieszony. Może również dojść do wstrzymania, przeciąnięcia lub odwrócenia którejś z faz podrzędnych;

3) trzecie - [nieograniczona] wiara w moc sprawczą wolnych, demokratycznych wyborów, legitymizujących nowe władze; w tym kontekście wybory postrzegane są nie jako pasywna podstawa, lecz jako aktywny element wpływu, generujący kolejne reformy;

4) czwarte założenie odrzuca znaczenie zastanych warunków: poziomu rozwoju ekonomicznego, historii politycznej, zależności instytucjonalnych, stosunków etnicznych, tradycji socjokulturowej oraz innych „strukturalnych” cech; Carothers krytykuje podejście, zapoczątkowane przez Dankwarta Rustowa w Transitions to Democracy: Toward a Dynamic Model, gdzie warunkiem przejścia był brak warunków - określone jako [gdy mowa o demokracji] „no conditions - anyone can do it!"; stąd, wg S. Huntingtona, znaczącą cechą wczesnego etapu trzeciej fali demokratyzacji była niezależność od owych warunków; czego dowodem są niespodziewane miejsca, w których wystąpiła: czy była to Mongolia, Albania czy Mauretania, wszędzie proces występował na przekór wzmiankowanym strukturalnym elementom; całe niezbędne działanie opierało się na decyzji elity politycznej [co do tego punktu nie żywię wewnętrznego przekonania, iż jest zgodne z rzeczywistościa];

5) piąte założenie dotyczy środowiska, w którym zachodzi tranzycja jego podstawą jest państwo; nie ma znaczenia stopień dysfunkcji, który ma w nim miejsce; ważne jest jedynie to, że zachodzi w jednostce politycznej określonej jako państwo i w jego granicach; obejmując 
zmiany parlamentarne, nowe instytucje wyborcze, reformy prawa w ramach istniejącego państwa.

Czy zatem, aby móc użyć wyrażenia tranzycja - musi istnieć założenie, że system ów kiedyś, choć nie ma na to warunków ideologicznych, politycznych, materialnych ani żadnych innych, przekształci się w demokrację? Czy jedyna czysta logika transformacji to taka, w której punktem wyjścia jest system niedemokratyczny, a rozwiązaniem - demokracja? Odpowiedź nie jest jednoznaczna. Transformacja, czy też używając anglojęzycznego określenia tranzycja określa tak przejście od systemu niedemokratycznego ku demokratycznemu [co jest podstawą koncepcji Huntingtona], lecz również - o czym wspomina niewielu autorów - przejściem od systemu demokratycznego do niedemokratycznego.

Istnieje - co zresztą podkreśla Z. Blok - tyle niemalże definicji transformacji, ilu badaczy podejmujących tę tematykę. Autor ów, definiując transformację systemową zestawia ją z transformacją ustrojową: ,transformacja systemowa bowiem to nie tylko problem techniczno-organizacyjny na wielką skalę, ani tym bardziej program polityczny czy gospodarczy jest to przede wszystkim proces zmian świadomościowych, polegający na przyjęciu zupełnie odmiennego systemu wartości, a więc posiadający w gruncie rzeczy duży wymiar ideologiczny. Losy transformacji rozstrzygną się wtedy, gdy społeczeństwo, w zasadniczej swej części, przyjmie za własny system wartości wyrosły z nowego ustroju społecznego"47. Istotne, iż autor zapisu zauważa duży dysonans i dowolność w sposobach precyzowania i deskrypcji owego terminu pomiędzy różnymi autorami oraz jego dostosowywanie do wymagań własnych koncepcji za proces naturalny.

Przychylam się tym samym - w znacznej części - ku rozumieniu transformacji użytej przez wrocławskich badaczy Bernarda Albina i Walentego Baluka w Białoruś. Dekada transformacji; wg których proces ów jest „w toku”. „Na Białorusi odbywa się obecnie proces umocnienia państwa stanowego [w rozumieniu Maxa Webera, w odróżnieniu od społeczeństwa nowoczesnego - przyp. M.M.], a na zmiany przyjedzie jeszcze poczekać [...]. Na Białorusi trudno uważać okres postkomunistycznych przeobrażeń za zakończony, tak jak to robi Jadwiga Staniszkis w przypadku Rosji. Twierdzi ona, że wraz z odejściem Borysa Jelcyna nastapił koniec pierwszej fazy transformacji, podczas której z instytucjonalnego i «układowego» dziedzictwa poprzedniego systemu stopniowo wyłoniły się instytucje

47 Z. Blok, Transformacja systemowa, s. 291. 
rynkowe i zaczyn «politycznego kapitalizmu». W przypadku Białorusi tego zaczynu jeszcze nie widać. Niniejsza inicjatywa Zakładu Badań nad Europą Wschodnią Instytutu Studiów Międzynarodowych Uniwersytetu Wrocławskiego polegająca na analizie okresu transformacji na Białorusi ma służyć przybliżeniu polskiemu czytelnikowi procesu przemian zachodzących u naszych wschodnich sąsiadów. Intencją redaktorów było przedstawienie procesów zachodzących podczas dekady transformacji, przy czym dekada nie jest tu zamkniętym procesem, lecz stadium trwających jeszcze przemian w różnych dziedzinach życia polityczno-społecznego, gospodarczego i kulturowego"48.

Ponadto, jak zauważa redaktor naczelny ukraińskiej „Myśli politycznej”, ,biorąc pod uwagę szeroką lekcję procesów transformacji, po pierwsze powiedzieć należy, że oczekiwania obu stron - tak państw przechodzących transformację, jak i Zachodu - były zbyt wysokie i raczej naiwne. Uwolnione społeczeństwa byłych państw komunistycznych miały wyolbrzymione oczekiwania i raczej prosty pogląd na rodzaj pomocy, którą otrzymają z Zachodu. Z obecnego punktu widzenia stwierdzić należy, iż panowało generalne niedocenienie kompleksowości zmian systemowych, które należało przeprowadzić i oporu stwarzanego przez wciąż silną i rozpowszechnioną nomenklaturę"49 .,Przykładu mogą dostarczać amerykańskie programy pomocowe, zainicjowane zaraz po 1989 roku dla Polski, a następnie dla pozostałych państw centralnej Europy. Wszystkie były bazowane na poglądzie, że przemiany zajmą maksymalnie pięć lat"50. Historia pokazuje, że „dla Europy Centralnej proces ten zamyka się w minimum 10 latach, dla pozostałych - tj. dla Europy Wschodniej trwa minimum 15-20 lat [...]. Drugą i bardziej skomplikowaną lekcją jest to, że proces transformacji nie jest continuum, lecz sekwencją wyróżnialnych faz. Co więcej, nie wszystkie państwa postkomunistyczne zaczynały z tego samego pułapu, ani też nie przechodziły wszystkich faz. Zależało to w dużej mierze od tego, co wynikało politycznie i gospodarczo z ostatniej fazy

48 B. J. Albin, W. Baluk, Dekada Transformacji. Białoruś, Wstęp, Wrocław 2004, s. $13-14$.

49 W. Połokhajło, The Stages of Postcommunist Transformations, w: The Political Analysis of Postcommunism, red. W. Połokhało, s. 104. Połokhajło jest dyrektorem jednego z najważniejszych, prócz Centrum Razumkowa i NISPI, ukraińskich think-tanków - redakcji „Politicznoj Dumki”.

50 Raport US General Accounting Office: Poland and Hangary-Economic Transition and US Assistance, maj 1999, s. 18-26 oraz 30. 
poprzedniego komunistycznego systemu - z fazy tzw. implozji lub powstania" 51 .

Pomijając kwestię definicji ,procesu” (gdyż dostatecznie jasno rozwinięta jest ona m.in. przez A. Antoszewskiego w Studiach z teorii polityki, t. II, s. 193 i n.), stwierdzić należy, lecz z powyższymi zastrzeżeniami - za Z. Blokiem - iż transformacja ,jest nazwą mniej lub bardziej sprecyzowanego procesu historycznego [...]. Zgodnie z takim pojmowaniem transformacji nie definiuje się jej w ogóle, podobnie zresztą postępowano i wcześniej. Używa się więc takich nazw jak okres transformacji, era transformacji, doba transformacji”. Kontynuuje jednak: „Istnieje też grupa badaczy, którym nie odpowiada termin transformacja i poszukują własnych pojęć, które są bardziej funkcjonalne na gruncie respektowanych przez nich założeń teoretycznych i realizowanych programów badawczych" ${ }^{32}$. Owe rozbieżności nomenklaturowe nie wspomagają ujednolicenia nomenklatury i rozumienia; wymagając jednocześnie wstępnego przebrnięcia przez pewną liczbę teorii pretendujących do wyłączności. Być może wygodnym, choć niezbyt eleganckim rozwiązaniem byłoby w pełni instrumentalne potraktowanie wyrażenia „w warunkach transformacji”, tak jak postapił m.in. w III tomie Studiów z teorii polityki A. Czajowski, który pisząc o transformacji nie zdefiniował jej ani razu w całym tekście ${ }^{53}$.

\section{Mierzenie demokracji. Reżimy niedemokratyczne}

Nie istnieje consensus co do sposobu mierzenia demokracji; jej definicje są kontestowane, a dyskusja czym jest demokracja trwa. Kwestia nie jest czysto akademicka - promowanie demokracji jest m.in. na liście priorytetów amerykańskiej polityki zagranicznej, aby zaś coś promować należy brutalnie wiedzieć co. Jeden z wpływowych obserwatorów owej polityki stwierdził, że ,jedyna światowa potęga retorycznie i militarnie promuje system polityczny, który pozostaje niezdefiniowany; wystawiając swoją powagę i skarb na ryzyko"54. Stąd demokrację można oceniać na niwie

51 W. Połokhało, The Stages of Postcommunist..., s. 105

52 Z. Blok, Teoria polityki. Studia, Poznań 1999, s. 104.

53 A. Czajowski, Zasada państwa prawnego $w$ teorii i praktyce (w warunkach transformacji ustrojowej Rosji), w: Studia z teorii polityki, t. III, red. A. Czajowski, L. Sobkowiak, Wrocław, s. 183 i n.

54 Za: L. Kekic, Democracy Index, The Economist Intelligence Unit's index of democracy, „Economist Intelligence Unit” 2007, Horowitz 2006, s. 114. 
teoretycznej [definicja demokracji idealnej/poliarchii Dahla, proceduralnej Schumpetera, w której „władza jest zdobywana przez rywalizacyjne starania o uzyskanie głosu wyborcy" ${ }^{\text {,5 }}$, jako konsekwencję rewolucji technologicznej Lipseta i Rokkana etc.] lub jako zestaw praktycznych reguł i zasad instytucjonalizujących i chroniących wolność - z którą demokracja jest często wymiennie, choć nieprawidłowo [nie są to wyrażenia synonimiczne] stosowana/utożsamiana. Niektórzy badacze nastają na dychotomiczne rozumienie demokracji; inni pozwalają sobie na jej stopniowanie. Przyjęte przez Unię Europejską kryteria zwerbalizowane są w kopenhaskich kryteriach członkostwa w Unii Europejskiej ${ }^{56}$; zaś prowadzący badania od 1972 roku Freedom House ocenia stopień demokratyzmu pod kątem wolności politycznej opartej na 10 kryteriach, swobód obywatelskich opartych na 15 kryteriach [łącznie] [indeks badawczy obejmuje wszystkie państwa świata w siedmiostopniowej skali]. FH prowadzi również oddzielny indeks wąsko pojmowanej demokracji - tzw. demokracji elektoralnej [FH > 2.0], czyli systemu, który może wykazać się wolnymi, regularnymi i uczciwymi wyborami [jawne i powszechne regularnie realizowane wybory: Wolff-Powęska, Oswojona rewolucja..., s. 45]. Przy owym „minimalistycznym” standardzie brane pod uwagę są jedynie cztery kryteria:

1) rywalizacyjny system multipartyjny;

2) uniwersalne/powszechne prawo wyborcze dla dorosłych;

3) regularnie przeprowadzane wybory na bazie tajności, bezpieczeństwa list wyborczych i nieobecności masowych fałszerstw;

4) znaczący/znaczny dostęp publiczny głównych sił politycznych/partii do elektoratu poprzez media i poprzez otwarte kampanie.

Przy czym, jak pyta L. Diamond ,akceptując definicję S. Huntingtona, czy system jest demokratyczny, jeśli jego najsilniejszy kolektyw decyzyjny jest wybrany przez uczciwe, wolne, powszechne i regularne wybory, w których kandydaci bez ograniczeń rywalizuja o głosy? Co w takim razie

55 J. Schumpeter, Capitalism, Socialism and Democracy, NY 1947, s 269; polskie wydanie Kapitalizm. Socjalizm. Demokracja, w przekładzie M. Rusińskiego, PWN, Warszawa 1995.

${ }_{56}$ Patrz m.in. www.eu2002.dk/ewebeditpro2/upload/OW.Headline/130/EU\%20UK.pdf, polska wersja: Spotkania Rady Unii Europejskiej 1993-2002. Monitor Integracji Europejskiej. Zjednoczona Europa. Program prezydencji duńskiej w Unii Europejskiej, lipiec-grudzień 2002, rozdział Kryteria kopenhaskie oraz Prawo Unii Europejskiej, red. A. Łazowski, C. H. Beck, Warszawa 2004, s. 208. 
konstytuuje uczciwe, wolne i powszechne? Skąd wiemy, że partie miały uczciwą szansę na kampanię i że wyborcy w danym kraju (a szczególnie w dużych i niehomogenicznych państwach jak Rosja, Nigeria czy Indonezja) mogli wyrazić swoją wolę w sposób nieskrępowany? [...]. Skąd wiemy że najsilniejszy kolektyw decyzyjny jest rzeczywiście tym, za który się podaje? Że nie jest [utajoną - wtrącenie moje. M.M.] domenq zarezerwowana dla wojska, biurokracji lub oligarchii?",57.

Jak stwierdza L. Diamond, „ostatnio rosnąca liczba badaczy kwestionuje tendencję do klasyfikowania reżimów jako demokratyczne tylko dlatego, że mają multiparty elections with some degree of competition and uncertainty. Jest to ważna kontrybucja konceptualna, skupiona na Eurazji i Ameryce Łacińskiej. Zaś Steven Levitsky i Lucan Way argumentują, że reżim może być jednocześnie rywalizacyjny i autorytarny ${ }^{58}$. W anglosaskiej doktrynie przeciwieństwem systemu demokratycznego jest system autorytarny; rozumiany - lecz nie wyróżniany - jako totalitarny/autorytarny w polskiej nomenklaturze politologicznej. A. Łopatka uważa, że „W reżimie autorytarnym aparat państwowy nie podlega kontroli ze strony społeczeństwa, sam określa cele i zadania państwa, nie uważa w praktyce, że jest ograniczony prawem, czując się od niego niezależnym, często ucieka się do przemocy w stosunku do ludności kraju" ${ }^{, 59}$.

Axel Hadenius i Jan Teorell, w Authoritarian Regimes: Stability, Change and Pathways to Democracy, 1972-2003 przedstawili nowy podział reżimów autorytarnych ${ }^{60}$. Punktem wyjścia była konstatacja, że różne rodzaje reżimów autorytarnych podlegają różnym inklinacjom podczas przekształcania $\mathrm{w}$ demokrację oraz stwierdzenie, że oparte na koncepcji trzeciej fali deskrypcje nie spełniają swojej roli; zakładając, że wszystkie autorytarne reżimy są identyczne. Ich podział nie ma charakteru unikalnego; od kilku lat w anglojęzycznej nomenklaturze politologicznej używa się pojęć hybrid regime, na reżim ulokowany pomiędzy systemem demokratycznym a autorytarnym, w tzw. szarej strefie [gray zone $]^{61}$. Aczkol-

57 L. Diamond, Elections Without Democracy. Thinking about Hybrid Regimes, „Journal of Democracy” kwiecień 2002, vol. 13, nr 2, s. 22.

58 Ibidem, s. 23.

59 A. Łopatka, Prawoznawstwo, Iuris, Warszawa 2001, s. 41.

60 A. Hadenius, J. Teorell, Authoritarian Regimes: Stability, Change and Pathways to Democracy, 1972-2003, Working Paper \#331 - November 2006.

${ }^{61}$ Patrz: B. Geddes, What Do We Know about Democratization after Twenty Years?, „Annual Review of Political Science” 1999, s. 115-144; L. Diamond, Thinking about Hybrid Regimes, „Journal of Democracy” 2002, nr 13(2), s. 21-35; 
wiek - jak przyznają autorzy - ich podział jest bazowany na strukturze pracy seminaryjnej Barbary Geddes ${ }^{62}$; do rąk czytelnika trafia znacznie rozszerzony jakościowo podział. Geddes wydziela autorytarne reżimy militarne (wojskowe), personalistyczne (osobowe) oraz systemy jednopartyjne. Wg Geddes, o czym świadczą m.in. procesy w historii powojennej, najbardziej nietrwałymi strukturami są reżimy wojskowe, których czasookres trwania jest najkrótszy. Pośrodku plasują się reżimy osobowe, najdłużej zaś trwają systemy jednopartyjne. Hadenius i Teorell umniejszają znaczenie reżimów personalnych [osobowych] ${ }^{63}$, wydzielają reżimy z partią wiodąca [czego brakuje u Geddes], dodają monarchie i ograniczone multipartyjne autokracje oraz - inaczej niż Geddes - nie twierdzą, że upadek reżimu niedemokratycznego oznacza jednocześnie powstanie reżimu demokratycznego [vide wzmiankowana propozycja metodologiczna szarej strefy]. Za charakterystyczny, i przydatny w niniejszym dyskursie, postrzegać należy jeden z zapisów poczynionych przez autorów przy deskrypcji skali demokratyzmu systemu [opartym m.in. na klasyfikacji Freedom House, (badania od 1972 roku), Polity score ${ }^{64}$ oraz badaniach m.in.

S. Levitsky, W. Lucan, The Rise of Competitive Authoritarianism, ,Journal of Democracy” 2002, nr 13(2), s. 51-65; A. Schedler, The Menu of Manipulation, „Journal of Democracy" 2002, nr 13(2), s. 36-50; J. Linz, S. Alfred, Problems of Democratic Transition and Consolidation: Southern Europe, South America, and Post-Communist Europe, Johns Hopkins University Press, Baltimore 1996; J. Linz, Totalitarian and Authoritarian Regimes, Boulder 2000.

${ }_{2}$ B. Geddes, What Do We Know about Democratization after Twenty Years?, „Annual Review of Political Science”, s. 115-144.

${ }^{63}$ B. Geddes: „Reżimy osobowe, co jest naturalne, wykazują dużo większą zwartość, i tym samym nie upadają tak łatwo. Ponadto, mają tendencję do ukorzeniania się w społeczeństwie przez dużo bardziej rozbudowane sieci. Sieci te są zwykle zbudowane w oparciu o zasadę klientelizmu. Rezultatem jest zapewnienie lojalności wśród najważniejszych grup w społeczeństwie; taka lojalność jest raczej pragmatyczna, jakkolwiek, oparta na dość zaawansowanej dystrybucji (i konsumpcji) zasobów ekonomicznych. W tym samym czasie, przewidywania co do długookresowej stabilności reżimów personalnych są raczej widziane w ciemnych barwach: zasadą jest, że ci którzy doszli do szczytów władzy są całkowicie zależni na swych pozycjach od rządzącego lidera. Jeśli lider upadnie - stracą wszystko. Stąd mają silną motywację by go popierać i przetrzymać możliwe zmiany maksymalnie długo jak to jest możliwe. To wszystko daje reżimom osobowym dużo większą stabilność w porównaniu z reżimami militarnymi”. Patrz przypis dot. klanowości w systemach postsowieckich/łukaszenkowskich elit medialnych.

${ }^{64}$ Patrz: Center for International Development and Conflict Management [CIDCM], projekt Polity $I V$. 
Przeworskiego $\left.{ }^{65}\right]$ : „[w ściśle określonych warunkach następuje $]$ natychmiastowa tranzycja od autokracji do demokracji [lub] [...], natychmiastowa tranzycja od demokracji do autokracji”. Pomijając bezpośrednią merytoryczną zawartość, cytat ów wskazuje na zamienne stosowanie tranzycji i transformacji.

Przy określeniu procesu przejścia panuje wśród badaczy pewna dowolność. Brak jasnych kryteriów oceny, krytyczny stosunek do propozycji nomenklatury Huntingtona czy też zwykły niepewność powoduja, że transformacja oraz tranzycja często współwystępują w pracach tych samych autorów bez poczynienia rozróżnienia czy zastrzeżeń. Niektórzy autorzy, jak m.in. Krygier i Czarnota uważają, że jest co całkiem uzasadnione z racji niemożności wydzielenia cech tak charakterystycznych, by były one do zaakceptowania dla większości badaczy ${ }^{66}$. Stąd, choć większość anglojęzycznych badaczy posługuje się terminami: tranzycja, reżim w okresie tranzycji, w stanie tranzycji, napotkać można również na użycie określenia transformacja [transformation], czego dowodem mogą być m.in. wzmiankowane już teksty L. Diamonda, jednego z redaktorów „Journal of Democracy” wydawanego przez John Hopkins University, wiceprezesa National Endowment for International Peace oraz senior fellow w Instytucie Hoovera ${ }^{67}$; jednego z najbar-

${ }^{65}$ A. Przeworski, M. Alvarez, J. A. Cheibub, F. Limongi (red.), Democracy and Development: Political Institutions and Well-Being in the World, 1950-1990, Cambridge University Press, Cambridge 2006.

${ }^{66}$ „W świetle tak stałych źródeł problemów, można znaleźć - odwrotnie niż u poważanych tranzytologów - mnóstwo indywidualnych studiów i wydanych zbiorów poświęconych konkretnym aspektom tego ogromnego problemu, pozostające agnostyczne w stosunku do generalnego charakteru procesu. Sygnałem takiego samoświadomego agnostycyzmu jest użycie słowa «transformacja» zamiast oryginalnie wszechobecnej «tranzycji». Jak precyzują nieskończone ilości prac w pierwszym paragrafie, tranzycja sugeruje, że wiemy gdzie podążamy. Transformacja natomiast określa jedynie fakt, że coś się dzieje. Wiele tekstów pojawiło się w zbiorach, wśród nich i nasze, przynosząc razem wielość perspektyw w przypadku konkretnych problemów, sugerując wspólne punkty odniesienia, włączając w to tematy tranzycja, lecz nie generujące jednogłosu paradygmatów opisu, ewaluacji lub rozwiązań. Jest mądrość w tym zastrzeżeniu. Wiele szybkich i poważnych sądów odnośnie rozwoju i kierunków postkomunizmu było datowanych raczej zbyt szybko. Oczywiście, wstrzymywanie się z mówieniem o tranzycji nie jest zawsze znakiem ostrożności. Może być również znakiem braku zgody (patrz: Carothers 2002). Tranzycja jest sytuacją lub stanem, lub oswobodzeniem - jeśli wolisz - rodzajem nieokreślonej lecz wskazanej trajektorii od znienawidzonej przeszłości do liberalnej przyszłości”.

${ }^{67}$ „The transformations of Taiwan, Mexico, and Senegal in the 1990s show that competitive authoritarian regimes can become democracies. But democracies, new 
dziej znanych i najczęściej cytowanych autorów w rzeczonej materii czy T. Catorhersa lub B. Geddes, A. Croissant i W. Merkel. Od tego podejścia nie stronią również rosyjscy i ukraińscy badacze ${ }^{68}$.

Aurel Croissant i Wolfgang Merkel, w Democratization in the Early Twenty-First Century ${ }^{69}$, pisząc o dylemacie symultaniczności ${ }^{70}$ powołuja się na Timma Beichelta, podejmującego znaczenie koncepcji defective democracy [uszkodzonej/wadliwej demokracji] dla badań nad transformacjami dla państw Europy Wschodniej, w szczególności dla postsowieckich republik. Beichelt, opisując w 2004 roku sytuację Rosji, Ukrainy, Mołdowy i Białorusi użył sformułowania reversed transition odwróciła/odwrócona tranzycja ${ }^{71}$; co zasadniczo zgodne jest z koncepcją Jabłońskiego o transformacji/tranzycji jako o procesie nie tyle odwracalnym, co mogącym mieć odwrotny kierunek od tego, który jest postrzegany jako klasyczny - tj. od reżimu niedemokratycznego do demokratycznego.

W rosyjskojęzycznej nomenklaturze coraz częściej pojawia się pojęcie upravliajemaja demokratia - demokracja zarządzana, wspomagana, sterowana; pojęcia tego używa m.in. Igor Kljamkin w tekście Situatiwnoje gosudarstwo: ,demokracja sterowana dopuszcza przeprowadzenie wyborów, wynik których w znacznym stopniu wcześniej określony jest przez wykorzystanie «zasobów administracyjnych». Demokracja sterowana dopuszcza istnienie politycznej opozycji, ale - pozbawionej politycznego

and old, liberal and illiberal, can also become more democratic", za: L. Diamond, Elections Without Democracy. Thinking about Hybrid Regimes, ,Journal of Democracy" kwiecień 2002, vol. 13, nr 2, s. 34; wcześniej s. 26.

${ }^{68}$ M.in. Ihor Burakovsky w The Crisis of Transformations and the Strategy of Controlled Shock wymiennie używa - bez objaśnień - wyrażenia transformacja oraz tranzycja podejmując kwestię przemian. Patrz: I. Burakovsky, The Crisis..., „Politiczna Dumka”, nr 1/95, Kijów, s. 132.

${ }^{69}$ A. Croissant, W. Merkel, Democratization in the Early Twenty-First Century, „Democratization” December 2004, vol. 11, no. 5, s. 1-9.

70 J. Elster, The Necessity and Impossibility of Simultaneous Economic and Political Reform, w: Philosophy of Social Science, red. P. Polszajski, Warszawa 1990, s. 309-316; C. Offe, Das Dilemma der Gleichzeitigkeit. Demokratisierung und Marktwirtschaft in Osteuropa, „Merkur” 1991, no. 45, s. 279-292; C. Offe, Der Tunnel am Ende des Lichts. Erkundungen der politischen Transformation im neuen Osten, Frankfurt am Main 1994; J. Elster, C. Offe, Institutional Design in Post-Communist Societies. Rebuilding the Ship at Sea, Cambridge 1998.

71 T. Beichelt, Autocracy and Democracy in the European CIS, Manuscript for Democratization, Revised version, January 14, 2004. 
wpływu i możliwości pretendowania do władzy. Demokracja sterowana dopuszcza swobodę słowa i informacji, ale jedynie w tym zakresie, w którym ta swoboda nie zagraża władzy biurokratycznego wertykalu i nie pociaga jej pod odpowiedzialność przed społeczeństwem. Demokracja sterowana deklaruje zwierzchność prawa i niezawisłość sądu, ale jedynie przy zachowaniu przy władzy możliwości dowolnych zmian prawa i decyzji sądów - ale wyłącznie dla tych, którzy chcieliby zmienić demokrację ze sterowanej na sterującą. Demokracja sterowana deklaruje prawo własności, ale gwarantuje je tylko tym, którzy zgadzają się traktować to prawo jako umowno-warunkowe i są gotowi dzielić się swoją własnością z ludźmi, którzy demokracją sterują. Demokracja sterowana, traktując rzecz całościowo, dopuszcza istnienie tylko takiego społeczeństwa, w którym nie ma obywateli-podmiotów, lecz obywatele-przedmioty zarządzania $^{72}$, gotowe przyjmować przypisywane im odgórnie prawa gospodarcze i gry politycznej, traktujący owe prawidła jako demokratyczne i legalne. Lub - mówiąc wprost - społeczeństwo, które nie ma być przekształcone w obywatelskie" ${ }^{\text {,3 }}$. Andrzej Wawra, były pracownik kremlowskiej administracji prezydenckiej, posługuje się podobnym, lecz rdzeniem nieco odmiennym terminem - suwerenna demokracja ${ }^{74}$, zaś pewna część rosyj-

72 Patrz m.in. J. Mettke, Pomocnicy cara Putina, „Der Spiegel”, 2 czerwca 2006, o skompletowaniu i zwołaniu - identycznie jak wcześniej na Białorusi - tzw. Izby Społecznej, ,nowego ciała nadzorczego i przedstawicielskiego ds. rosyjskiego społeczeństwa obywatelskiego; klubu szacownych Rosjan, dobranych według wzoru sowieckiego i mających prawo zabierać głos w polityce, lecz nie mających prawa o czymkolwiek decydować".

${ }^{73}$ I. Kliamkin, Situatiwnoje gosudarstwo, w: Wniz po wertikali. Uprawljajemaja demokratia: hronika czetyreh liet, Moskwa 2005, s. 17 i n.

${ }^{74}$ Wawra w swoim tekście w „Niezawisimoj Gazietie” [Zmiana władzy, czyli rosyjski skrót myślowy, NG, 20 października 2006 roku], krytykując/parafrazując W. Putina stwierdza: „stusznie, powinniśmy budować swa demokrację, opierajac się na własnym doświadczeniu historycznym i tradycji, a nie wedlug cudzych recept i przekalkowanych rozwiqzań. Prawo i obowiqzek życia w zgodzie ze swoja kultura i tradycjami powinniśmy stawiać wyżej niż kierowanie się cudzymi prawami i regułami. Cała bieda w tym, że parametry naszej suwerennej demokracji wymyślane są w biegu i dostrajane do celów politycznych. W rezultacie demokracja u nas to ta praktyczna polityka, którą realizuje władza [...]. Obecnie pojęcie suwerenna demokracja spełnia funkcję obronna, akcentuje negatywne nastawienie [co] może nam się przydać w wyborach w 2008 roku, gdy posypią się na nas zarzuty, że wybory są nierównoprawne, faktycznie bezalternatywne, że procent głosów oddanych na kandydata do władzy stawia nas w jednym szeregu z Białorusią i Kazachstanem". 
skich komentatorów politycznych ukuła określenie neoautorytaryzm, rozumiany jako autorytaryzm ograniczony przez nieodwracalne procesy globalizacji ${ }^{75}$.

$$
* * *
$$

Przychylić się należy ku zwartej analizie Marka Bućko, iż białoruski model polityczny jest dyktaturq o charakterze faszystowskim lub co najmniej ewoluuje w tym kierunku: „system władzy w pełni wyczerpuje kryteria charakterystyczne dla faszyzmu lub neostalinizmu: istnieje silny wódz bezpośrednio kontrolujący wszystkie segmenty władzy oraz jego masowy kult, planowo wdrażana (również jako przedmiot szkolny i akademicki) ideologia państwowa obejmuje, definiuje i ingeruje we wszystkie dziedziny życia (włącznie z religią, kulturą, literaturą, rozrywką, nauką, wychowaniem młodzieży, programem mediów, sportem), z założenia negując jakiekolwiek alternatywne lub niezależne postawy społeczne. Istniejące instytucje demokratyczne (parlament, Sąd Najwyższy i sądy niższego szczebla) są nimi tylko z nazwy, służąc wyłącznie jako fasada władzy wykonawczej, instytucja wolnych wyborów w praktyce nie istnieje, partie opozycyjne i media niezależne są coraz szybciej i z pogwałceniem prawa administracyjnie eliminowane z życia politycznego, mniejszości narodowe i religijne są prześladowane i nie mogą się rozwijać, protesty społeczne są praktycznie niemożliwe, służby specjalne dysponują ogromnymi uprawnieniami i pozostają poza jakąkolwiek kontrolą społeczną, w niektórych przypadkach władza ucieka się do zabójstw politycznych, a w sposób masowy stosuje mechanizm zastraszania lub «pobicia przez nieznanych sprawców», areszty, zwolnienia z pracy, grzywny. Kultura państwowa opiera się na etosie ludowo-militarystycznym, kulcie «braterstwa radziecko-słowiańskiego» jako przeciwstawnego «wrogiej kulturze Zachodu» i wpływom katolicyzmu, przy coraz częściej obecnych elementach antysemickich, antypolskich, antyprotestanckich i wrogich nawet narodowej kulturze białoruskiej"76. Podobnego zdania jest Mariusz Maszkiewicz, były ambasador RP w Mińsku: „mamy do czynienia z pewnym liftingiem syste-

75 Określenie to używane jest często zamiennie z terminami: operacja wyniesienie, kagiebizacja Kremla, pagonizacja administracji czy pełzajacy przewrót czekistów.

76 Polska polityka wschodnia, zapis konferencji z dnia 28-29 października 2005 roku we Wrocławiu przez Kolegium Europy Wschodniej, s. 149-150. 
mu sowieckiego" ${ }^{, 77}$; zaś Wiktor Czarnou (Czarnau), analizując naturę reżimu wydziela jego cele w następujący sposób:

- konsolidacja władzy Aleksandra Łukaszenki i przedłużenie jego rządów jak długo jest to możliwe;

- restauracja, modyfikacja i utrzymanie podstawowych aspektów byłego sowieckiego porządku;

- rozszerzenie wewnętrznej kontroli na te części społeczeństwa, które są wciąż niezależne od reżimu;

- rozszerzenie zewnętrzne ku braterskiej Rosji, która jest bogata w naturalne zasoby; co doprowadzić może [lecz jest to nierealistyczne] do przejęcia tam władzy.

\section{Summary}

The terminology developed to serve the needs of stable Western democracies fails with respect to the republics that emerged following the collapse of the USSR. This may be confirmed by the notion of the 'grey zone', assisted democracy, managed democracy or electoral democracy. The Belorussian transition process seems to be work in progress. Its closure would demand that the current state be acknowledged as being stable rather than transitional. A unanimous assessment is not assisted by the terminological divergence that is indispensably accompanying transformation, transition or the period of transition, as termed in the Russian language, which seems to be the best description of the process. The analysis does not apply the dichotomist approach to democracy, either, where democracy is considered to be either present or absent, since it is impossible to identify the nondemocratic elements of the system unanimously. T. Carothers, who was critical of Huntington's Third Wave, claims that when the key elements of a political system are appropriately manipulated for the benefit of a heuristic analysis it results in a political system of managed democracy to be a priori acknowledged to be a democratic one. The tools of analysis developed for the needs of stable Western democracies fail when faced with a new type of personal, party or military dictatorship, or with neoauthoritarianism, understood as authoritarianism altered by the irreversible globalization processes.

77 Dr Mariusz Maszkiewicz - pracował jako dyplomata w Wilnie, następnie jako konsul generalny RP w Grodnie, a w latach 1998-2002 był ambasadorem RP w Mińśku. Patrz również: M. Ikonowicz, Sowieckie metody Eukaszenki, „Przegląd”, 4 sierpnia 2005 r. 